\title{
Determinants of the Export Performance of Tunisian SMEs: Analysis Trough the MICMAC Method
}

\author{
Mohamed Sofien Nouri $^{1 *}$, Younes Boujelbene ${ }^{2}$ \\ ${ }^{\mathrm{T}}$ Doctor in Economic Sciences, FSEG of Sfax, University of Sfax, Tunisia \\ ${ }^{2}$ Professor in Economic Sciences, FSEG of Sfax, University of Sfax, Tunisia \\ *Corresponding Author \\ Mohamed Sofien Nouri \\ Doctor in Economic Sciences, FSEG of Sfax, University of Sfax, Tunisia
}

\author{
Article History \\ Received: 02.12.2021 \\ Accepted: 05.01.2022
}

Published: 15.01.2022

\begin{abstract}
Exporting companies survive in an increasingly volatile and unpredictable environment, characterized by technological development and acute competition linked to the globalization of economic activities. Exporting has a positive impact on the trade balance of countries, especially in times of crisis, on the level of employment and on the improvement of the standard of living in general. The challenges faced by exporting companies and the actions they need to take in order to be more successful must be systematically addressed. The authors of this article have highlighted the key factors that can help companies to be more competitive and successful in exporting, based on theoretical approaches carried out in this field. The MICMAC method was used to identify the determining factors that can influence the performance of companies in exporting. The variables used in this research were identified based on the review of existing literature. 21 variables were collected and classified into 7 themes. The results of the structural analysis were prioritized by performing a sensitivity analysis to prioritize the key factors. It was found that three factors condition the export performance of firms: strategic factors, management profile, commitment and international experience were found to be related to the export performance of the firm. The results of this research were used to develop recommendations for business leaders, practitioners and policy makers. The authors hope that this advice would help Tunisian firms' export performance in the future.
\end{abstract}

Keywords: Performance, export, environmental characteristic, international experience, international commitment, MICMAC analysis.

\section{INTRODUCTION}

The export performance of firms has been of interest to researchers and practitioners for several years. Today, due to globalization, all companies in different industries are facing intense competition. Under this pressure, exporting companies should have appropriate skills and strategies. Exporting on the part of SMEs is considered a key strategic move due to the benefits they provide (Damoah, 2018). Indeed, exporting has a positive impact on countries' balance of trade, job creation, and overall living standards (Freeman and Styles, 2014). It also stimulates socioeconomic prosperity (Mansion and Bausch, 2020). Despite these benefits, many SMEs remain reluctant to enter export markets, often fearing non-export performance (Mansion and Bausch, 2020). The literature informs us of several variables that are able to influence the performance of exporting SMEs. Giarratana and Torrisi (2010) argue that the export performance of firms is determined by several factors.

\section{LITERATURE REVIEW}

A. Export strategy

Exporting firms rely on both adaptation and differentiation strategies to gain competitive advantage in foreign markets.

Copyright (C) 2022 The Author(s): This is an open-access article distributed under the terms of the Creative Commons Attribution 4.0 International License (CC BY-NC 4.0) which permits unrestricted use, distribution, and reproduction in any medium for noncommercial use provided the original author and source are credited. 
Porter (1980) argues that business strategies are the policy and stance that a business entity adopts in response to its competitive business environment and a set of values or products that it develops in order to gain market share over its competitors. Chen and Keung (2019) argue that business strategies can be characterized by how firms decide to compete, pursue, achieve, and maintain their competitive advantage. Porter (1980) argues that there are three business strategies that a firm can choose to employ, cost dominance, differentiation, and focus strategy. The differentiation strategy creates brand loyalty and thus provides profitability for the firm. Similarly, it weakens price sensitivity on the part of customers who are willing to pay higher prices (Porter, 1985).

In a study to investigate the impact of competitiveness on the performance of exporting SMEs, Naniki (1988) reports that these firms exploit four types of strategy:

- A marketing differentiation strategy that focuses on competitive pricing, brand development, distribution control, advertising, and innovation in marketing techniques.

- A segmentation differentiation strategy that focuses on offering new or specialty products to specific customer groups

- A strategy of differentiation through innovation which is based on offering technologically superior products and developing new products.

- A product-oriented strategy based on the quality of products and customer services.

By adapting the elements of the marketing mix to the destination markets, managers have the opportunity to gain market share by taking into account cross-cultural differences. In their study, Calantone et al., (2006) found that there is a positive relationship between export performance and product adaptation strategy. The marketing mix strategy emphasizes the cultural differences and regulations of foreign markets to form the ultimate strategy (Helm and Gritsch, 2014). Product adaptation strategy is defined as the planned and conscious activities of a company to satisfy and meet the tastes and preferences of local consumers (Calantone et al., 2006). Exporting firms use the adaptation strategy to achieve sales growth and improved profitability. By relying on the pricing strategy, exporters aim to increase the number of foreign customers to achieve economies of scale (Leonidou et al., 2002). The effects of promotion-related variables, (such as advertising, sales promotion), positively influence the export performance of firms. (Leonidou et al., 2002).

\section{B. Innovation}

Innovative capability is important for the future of the firm because it reflects the willingness to support creativity and experimentation in the introduction of new products/services, technology and research and development (R\&D) in the development of new sales processes and new products (Lumpkin and Dess, 1996).

New product innovation is the creation and development of new products for foreign markets while process innovation tends to improve product quality and value for money. The innovation capability of the firm exerts a positive effect on its export flow performance (Arkolakis et al., 2018).

Several researches have shown the positive impact of innovation on the performance of exporting firms Downs and Mohr, 1976; Durand and Coeurderoy, 2001; Ben Ayed and Boujelben, 2014).

\section{The size of the company}

The characteristics of the company can be assessed on the basis of several indicators. The first indicator is the company's capital. Indeed, the larger the company's capital, the more resources it has and the easier it is to access sources of financing. Indeed, the larger the firm has more resources, and it is more capable of exporting its products (Wagner, 2001; Maurel, 2009).

The second indicator reflecting the size of the company is the number of employees (Hart et al., 1994). Indeed, the size positively influences the strategy adopted by the company and its export performance (Maurel, 2009; Singh, 2009).

Other studies consider that the size of the company negatively influences its performance. Large firms have diversified products, several strategies, and a high number of staff and departments. Therefore, the larger the size of the company, the greater the complexity within the company (Badriyah et al., 2015).

\section{The external environment}

How managers assess the firm's external environment is important to the firm's performance. Management pressures, past firm performance, strategic priorities, customer expectations, and environmental uncertainty can influence firm export performance. The adoption of a research and development partnership with external partners favours export performance (Lefebvre et al., 1998). When the quality of forecasting is relevant, management's assessment of the external environment will be effective (Bloemer et al., 2013). Indeed, the environment is dynamic and the working 
conditions are changing, so managers must propose solutions for the choice of export markets so that they are compatible with the environment of the company. Decisions on the choice of foreign markets are not systematic; they are mainly based on well-founded analyses (Alexander et al., 2007).

There are several criteria related to the choice of foreign markets: economic factors, geographical factors, technological factors, political climate, cultural environment, foreign trade policy are of great importance in the policy of choosing export markets by the company. (Miečinskienè, 2014).

\section{E. The international commitment}

A firm's international commitment is assessed by its inclusion in a process of internationalization both geographically and culturally that allows it to build the knowledge and capabilities necessary to become more exportoriented (Love et al., 2015). The degree of a firm's export commitment is determined by its degree of adaptation to the wants, needs, and expectations of its foreign intermediaries (Beamish et al., 1993). Commitment can be thought of as a firm's desire to maintain in-depth relationships with foreign customers (Bloemer et al., 2013). Therefore, commitment has a positive impact on the export performance of firms (Dritsaki and Stiakakis, 2014).

\section{F. International experience}

International experience is positively related to firm export performance (Johanson and Vahlne, 1977). Indeed, if the firm gains experience in the international market, its response to export uncertainties and risks will be effective, since it has experience with the characteristics of the foreign market (Kogut and Singh, 1988). International experience helps the firm to establish itself abroad. Therefore, experience is an asset for the firm to engage in internationalization (Clarke et al., 2013). Experience helps firms deal with environmental challenges and uncertainties. International experience can help firms overcome problems related to exporting (Kumlu, 2014). Especially after many years of experience, firms gain the skills to meet the expectations of foreign customers.

\section{G. The characteristics of the manager}

Several researchers have highlighted the relationship between the managers' own skills and the process of the performance of exporting companies. In this framework, Argenti (1976) considers that if the external factors can influence the performance of the company, they cannot however cause the failure of a well-managed company. Lelogeais (2004) considers that the deterioration of the company's situation is essentially due to management errors; in fact the drop in turnover and the decrease in demand for the company are essentially caused by the manager's poor evaluation of the market.

By profiling entrepreneurs, Michoud (1995) shows that the leaders of successful companies set goals and longterm strategies. Ropega (2011), on the other hand, points out that, the lack of entrepreneurial or managerial skills can lead to unexpected problems that will reduce the performance of the company.

\section{H. Financial resources}

The financial criterion of the performance of companies in exporting refers both to the internal aspect, through the company's own resources, and to the external aspect, through the lines of credit available to the company. Export activity is costly compared to local activity from the point of view of production characteristics, costs related to exporting, longer marketing times and higher uncertainties (St-Pierre, 2003). This may explain why some SMEs are reluctant to export. In fact, other studies support a positive link between the availability of financial resources in the firm and its export performance, since financial resources are an asset that allows exporting firms to compete effectively in foreign markets (Ling-Yee, Ogunmokun, 2001).

The second component is related to the size of the company, indeed the more the size of the company is important and the more it has fixed assets and the more the access to the credit lines will be easier. Indeed, the company which has resources has an advantage for the export of its products (Wagner, 2001; Maurel, 2009).

\section{METHODOLOGY}

\section{A. Data collection}

This study, which took place between 2018 and 2019, is qualitative and exploratory in nature and focuses on the factors that determine the performance of Tunisian companies in export. It is based on a research strategy in three phases. First, an exploration in the literature that allowed to extract the different data that determine the performance of the company in the export. Then, this list of data was organized into different themes. Next, we examined the data theme by theme and grouped them: in this step, several variables were grouped into one. This phase was followed by a brainstorming session between the experts (business leaders and professors of higher education) and the authors via video-conference. The first category of interlocutors is composed of researchers who have addressed the issue of company performance in their research work. In this context, we participated in several interviews during which we had 
the opportunity to present our problem and to obtain feedback that helped us to enrich our knowledge on the subject. Among the many researchers interviewed, two had already published on this subject.

The second category of interlocutors is made up of 50 managers of exporting companies belonging to various sectors of activity. The managers were selected on the basis of their professional experience in the export field.

Table I: List of experts involved

\begin{tabular}{|l|l|l|l|}
\hline Experts & Description & Domain & Experience \\
\hline Expert 1 & Professor & Academic & Over 17 years \\
Expert 2 & Professor & Academic & Over 15 years \\
Expert 3 & Researcher & Scientific research & Over 5 years \\
Expert 3 & Researcher & Scientific research & Over 4 years \\
Expert 3 & Manager & Industrial & Over 12 years \\
Expert 4 & Assistant Manager & Industrial & Over 10 years \\
Expert 5 & Assistant Manager & Industrial & Over 8 years \\
Expert 6 & Manager & Industrial & Over 5 years \\
Expert 7 & Manager & Commercial & Over 11 years \\
Expert 8 & Manager & Commercial & Over 8 years \\
Expert 9 & Assistant Manager & Commercial & Over 7 years \\
Expert 10 & Manager & Commercial & Over 7 years \\
Expert 11 & Manager & Service & Over 8 years \\
Expert 12 & Manager & Service & Over 7 years \\
Ex.13-54 & Manager & Various & less than 7 years \\
\hline
\end{tabular}

The experience of the researchers involved in this study helped us to identify appropriate variables and their respective groupings. This was followed by another brainstorming session between the experts and the authors to select and group the variables. The brainstorming session helped the authors finalize the analytical framework. The list of variables is structured into seven different themes. In total we submitted 21 variables to experts who reviewed, corrected and finally validated them (See Table II).

In the second step, we developed the structural analysis matrix based on the dependency status formulated by the experts and evaluated on a LIKERT scale ranging from 0 to 3 (See Appendix).

Table II: Factors that determine the export performance of companies

\begin{tabular}{|l|l|}
\hline Factors & Variables \\
\hline 1. Export strategies & - Product adaptation strategy (Var01) \\
& - Strategy of differentiation (Var02) \\
& - Strategy of cost domination (Var03) \\
\hline 2- Skills of the manager & - Basic training adapted to the company's field of activity (Var04) \\
& - Holding a foreign client portfolio (Var05) \\
& - Professional experience in the export business (Var06)
\end{tabular}

\section{B. Choice of the technique}

To carry out this research, we used the MIC MAC software (Matrix of Crossed Impacts-Multiplications Applied to a Ranking), created by the Laboratory of Innovation, Strategic Prospective and Organization (Lipsor). The purpose of 
this software is to treat the subject with a structural analysis. It is a systemic method, in matrix form, which analyses the relationships between the variables constituting the studied system and those of its explanatory environment. It includes three steps: The census of variables, the identification of relationships in the structural analysis matrix and the identification of key variables.

For the implementation of the method, three steps are to be distinguished:

- Identification of the concepts (ideas and/or variables) that structure the universe of thoughts of exporting company managers.

- Identify the links between the concepts using the Cross Impact Matrix. The variable dependency influence map is made up of concepts and links that are analysed using the Cross Impact Matrix (CIM) commonly used in prospective studies (Godet, 2001; Smida, 2010). This technique also makes it possible to rank the concepts in order of "preponderance" and "dependence".

- The concepts structuring the representations that managers have of export performance can be projected onto a plan of influences/dependencies.

The distribution of the concepts in relation to the different quadrants constructed around the center of gravity of this plane makes it possible to determine four major categories of variables that are differentiated according to their degrees of influence and dependence calculated from the MICMAC matrix. The abscissa axis represents the degree of dependence or sensitivity (column sum of the MICMAC) of the variables, the ordinate axis refers to their degrees of influence or drive (row sum of the MICMAC) and the center of gravity is relative to the influence mean, also equal to the dependence mean (Khelil et al., 2013).

This method makes it easy to identify the key variables of the problem using tables and graphs that allow for a modelling of the problem to be addressed. It is a tool for structuring ideas which allows to describe all the elements of the studied system and to put them in relation within a matrix. The study of these relations with the MICMAC method allows appearing the key variables to the evolution of the studied subject. The choice of this method was motivated by the sensitivity of the subject, indeed the determination of the factors able to lead to the performance of the companies to the export results rarely from a single factor, it is about a problem which requires the addition of several factors at the same time, which are interdependent and presenting a crossed correlation between them. Whatever the direction (positive or negative), the intensity (very weak, weak, average, strong) of the relationships expressed, the presence of a link between two concepts is coded by a number ranging from 0 to 3 .

\section{ANALYSIS OF THE RESULTS}

The analysis of the results will be based on the results offering a systemic vision to the studied phenomenon.

The identification of the variables that can influence the performance of companies in export is not sufficient; in fact, to identify the mechanism of performance in export it is necessary to understand all the relationships that link the variables between them. These relationships represent the explanatory environment of the system studied.

\section{A. Definition of relationships}

Structural analysis consists of relating the variables in a double entry table (structural analysis matrix). This is a step that requires a deep knowledge of the subject. The objective is to appreciate the direct influence relationships between the variables. This is where the insight of the analysis lies: the distinction between direct and indirect influence relationships.

A questionnaire was sent to the 50 experts (company managers) already involved in this research. This questionnaire is in the form of a double entry table presenting the variables initially selected in rows and columns. The response will be translated by an evaluation score on the Likert scale that varies from 0 to 3, reflecting the dependence of these variables on the subject relating to the determinants of the performance of export companies.

When there is no direct relationship of influence between two variables, a score of 0 is assigned. When, on the other hand, there is a direct relationship of influence between two variables, the relationship must be evaluated, or in other words, its importance must be estimated. When there is a strong influential relationship, a value of 3 was assigned. A value of 2 was assigned for a medium influence relationship and a value of 1 for a weak influence relationship.

The assessments collected from the experts resulted in the structural analysis matrix (See Appendix).

\section{B. The characteristics of the structural analysis matrix}

The size of the matrix refers to the number of variables we retained in the first stage of the structural analysis. Given that 21 variables were retained, the structural analysis matrix is composed of 441 cases. 
Of the 441 cases, we have: 199 times a "zero" or in other words, in $45.12 \%$ of the cases, we have identified that there was no direct influence between two variables, 161 times a "one" or in other words, in $36.5 \%$ of the cases, we identified a weak influence relationship, 61 times a "two" or in other words, in $13.83 \%$ of the cases, we identified a medium influence relationship, 20 times a "three" or in other words, in $4.53 \%$ of the cases, we identified a strong influence relationship (See Table III).

Table III: Characteristics of the structural analysis matrix
\begin{tabular}{|l|l|}
\hline INDICATOR & VALUE \\
\hline Matrix size & 21 \\
\hline Number of iterations & 2 \\
\hline Number of zeros & 199 \\
\hline Number of one & 161 \\
\hline Number of two & 61 \\
\hline Number of three & 20 \\
\hline Number of P & 0 \\
\hline Total & 242 \\
\hline Filling rate & $54,87528 \%$ \\
\hline
\end{tabular}

The results obtained from the MICMAC method relating to the degree of influence of the variables on the subject studied show that the export performance is strongly centered on the strategy adopted by the company in response to the expectations of the market (the variable Var01 presenting a power and a rather important degree of influence). Similarly, the degree of customer satisfaction (Var15) and international experience (Var20) have an influence on the company's export performance. As can be seen, several other variables influence the performance of companies in export with different degrees (in red: strong power of influence, and in green: medium power of influence) (See Fig 2).

\begin{tabular}{|c|c|c|}
\hline Rang & Variable & Variable \\
\hline 1 & 1 - Var01 & $16 \cdot \operatorname{Var} 16$ \\
\hline 2 & $14-$ Var14 & $14-\operatorname{Var} 14$ \\
\hline 3 & $16-\operatorname{Var} 16$ & 1 - Var01 \\
\hline 4 & $15-\operatorname{Var} 15$ & $3 \cdot \operatorname{Var} 03$ \\
\hline 5 & 21 - Var21 & 21 - Var21 \\
\hline 6 & 3-Var03 & $18 \cdot \operatorname{Var} 18$ \\
\hline 7 & $2 \cdot \operatorname{Var02}$ & $2 \cdot \operatorname{Var02}$ \\
\hline 8 & $18 \cdot \operatorname{Var} 18$ & $15 \cdot \operatorname{Var} 15$ \\
\hline 9 & $20-\operatorname{Var} 20$ & 8-Var08 \\
\hline 10 & $7-\operatorname{Var} 07$ & $20 \cdot \operatorname{Var} 20$ \\
\hline 11 & 8-Var08 & $7 \cdot \operatorname{Var} 07$ \\
\hline 12 & $6 \cdot \operatorname{Var} 06$ & 4 - Var04 \\
\hline 13 & $10 \cdot \operatorname{Var} 10$ & 6-Var06 \\
\hline 14 & $19 \cdot \operatorname{Var} 19$ & $10-\operatorname{Var} 10$ \\
\hline 15 & 4 - Var04 & $19 \cdot \operatorname{Var} 19$ \\
\hline 16 & $11-\operatorname{Var} 11$ & $17 \cdot \operatorname{Var} 17$ \\
\hline 17 & $17 \cdot \operatorname{Var} 17$ & 11 - Var11 \\
\hline 18 & $5 \cdot$ Var05 & 5-Var05 \\
\hline 19 & 9-Var09 & 9.Var09 \\
\hline 20 & $12 \cdot \operatorname{Var} 12$ & $13 \cdot \operatorname{Var} 13$ \\
\hline 21 & $13-$ Var13 & $12 \cdot \operatorname{Var} 12$ \\
\hline
\end{tabular}

Figure 2: Hierarchy of variables according to their influences

\section{Issues related to the performance of companies in export}

The third and final step in the structural analysis is the identification of key variables, which is done by the MICMAC software. This software calculates, from the structural analysis matrix, the impact of the previously identified relationships and thus has the ability to rank the variables. This method involves the development of a graph that ranks the factors based on driving power and dependency power.

Structural analysis reduces the complexity of the system of indirect relationships between factors, generating what are called influence-dependence planes. Each variable is associated with an indicator of influence and dependence, and thus positioned on the influence-dependence plane.

The influence-dependence space is divided into four quadrants grouping the variables studied. 


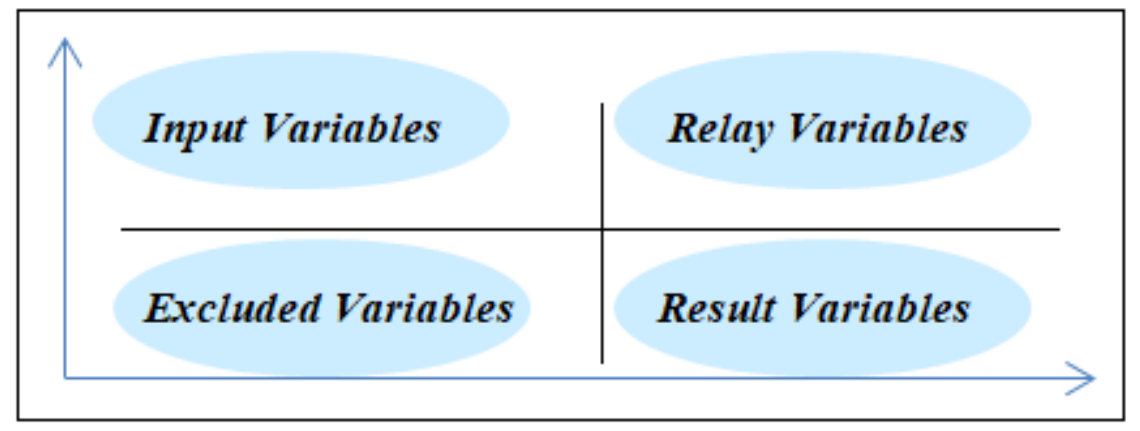

Thanks to this positioning, it is possible to distinguish 4 types of variables:

- Input variables: These are the variables that are highly influential and not very dependent on the other variables in the study. They are the explanatory variables of the subject studied.

- Relay variables: These are highly influential and highly dependent variables. The actions they undergo will be reflected in the entire study. They constitute the issues of the subject studied.

- The result variables: These are variables that have little influence and are highly dependent. The evolution of these variables can be explained by the evolution of the input and relay variables.

- Excluded variables: These are variables with little influence and little dependency. They do not have much impact on the evolution of the subject studied.

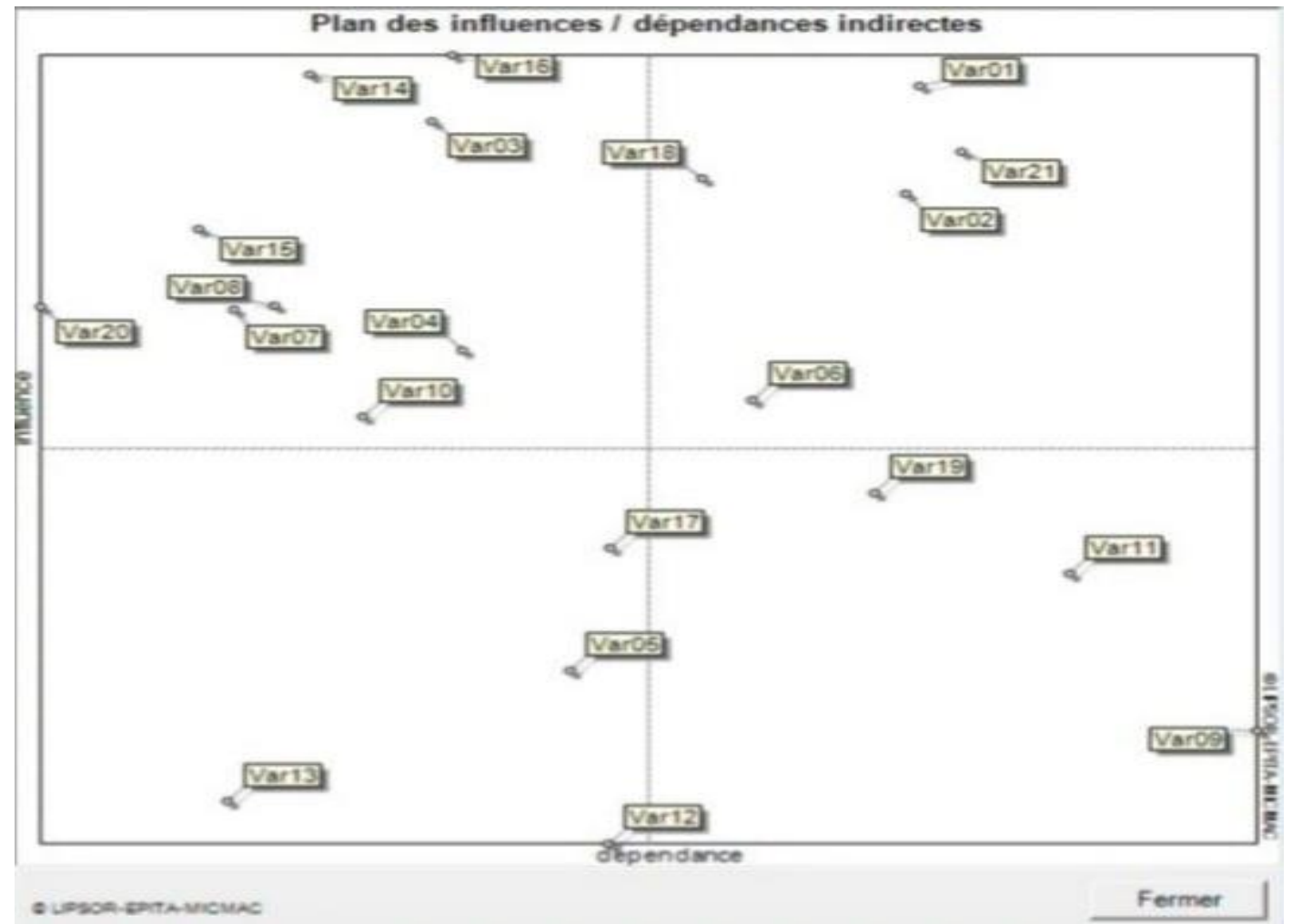

Figure 3: The influence-dependence plane for business performance factors

This classification allowed us to identify the relay variables, or in other words, the variables that constitute the issues of the subject studied: Corporate strategy:

- Adaptation strategy (Var01)

- $\quad$ Strategy of differentiation (Var02)

Competence of the manager:

- Professional experience in the export activity (Var06)

Commitment and experience in international business:

- Adaptation to the desires and expectations of its foreign intermediaries (Var21) 
The external environment:

- Well-founded study for the choice of foreign markets. (Var18)

\section{Discussion of the results of this research}

The current research was designed to identify and classify the essential factors that would help companies to be more successful in exporting in Tunisia.

From the examination of relay variables, we can see the importance of some factors that condition the performance of companies in the export in Tunisia, the first factor identified is the strategy of the company in the export. This factor is important because the policy adopted is crucial for the proper functioning of the company to satisfy its current foreign customers and even to attract new customers. The product adaptation strategy is of greater importance for the export performance, it is the set of measures taken by the company to meet the requirements of consumers in the target market. Similarly, according to the results obtained, we find that the differentiation strategy seems to be a key element in the performance of the company in the export market. This strategy must be based on the innovation of new products and new marketing concepts such as (the innovation of new packaging design, the improvement of after-sales service, etc. ...).

The empirical results from the structural analysis indicate that the factor, "Managerial competence", has a determining role in the performance of companies. This factor shows that the manager's own qualifications in terms of management, export experience and knowledge of the specificities of foreign markets constitute an asset for the company's export performance. This finding is confirmed by other studies that have proven that performance and growth indicators are most often related to managerial skills such as strategic planning and customer knowledge (Barringer et al., 2005; Wasilczuk, 2000, Erdil, and Özdemir, 2016 Haddoud et al., 2021).

Similarly, the factor "International commitment and experience" is a determining factor in the performance of companies in exporting. Indeed, international experience favors the management of environmental information, which is one of the main factors of performance of SMEs in international business. Similarly, international involvement favors the adoption of strategic intelligence practices on international performance. This finding is confirmed by the study conducted by Loghzaoui et al., (2013) in which they confirmed that the level of commitment to the international develops the sensitivity to information of leaders, and that the latter plays in favor of a greater dissemination of strategic intelligence activities within exporting SMEs.

The 'External environment' factor plays a predominant role in the performance of exporting firms. The latter implies that the choice of a market is a decision that must be taken after a thorough analysis of the company's capabilities in order to avoid export failure and serious risks for the company. Indeed, companies must adopt an approach that aims to identify the markets with the highest potential for their activities. Thus, the choice of the target market must be based on a series of criteria that will allow the company to succeed in its international development.

The relationship between the size of the company and the company's export performance is not decisive. The variables (Var12, Var13) that reflect the size of the firm are among the variables excluded from the system. This proves that the size is not a key element for the performance of the firm in export.

\section{CONCLUSION AND LIMITATIONS}

The research carried out was designed to identify the key factors that determine the performance of companies in exporting. Categories of seven main factors with 21 variables were selected, based on the theoretical studies conducted and the opinions of experts. This step was followed by the use of the Micmac technique, which was conducted to define the relationships between the variables. The structural analysis allowed us, through the identification of variables, to delineate and structure in a very precise way the factors leading to the performance of companies in the export in Tunisia.

At the level of this study, we were able to show the presence of internal and external factors that determine the performance of companies in export. Based on the structural analysis using the MIMAC method, it appeared that the specific characteristics of the firm, the international experience, the international commitment and the environmental factors were considered as having effects on the export performance. In addition, firm strategy is the most important determinant of firm export performance. The adoption of a differentiation and adaptation strategy based on innovation, which is able to meet customer expectations, seems to be a determining factor in the export performance of the company.

The survey conducted among leaders of exporting companies has produced interesting results for the Tunisian business environment. The strategy of the company, the profile of the manager, the international commitment and the international experience proved to be linked to the performance in export while the link is weaker between the characteristics of the company such as the size and its performance. The choice of export markets needs to be well 
analysed according to the firm's environment and competencies so that it can establish more differentiated and adaptive strategies for export performance.

This study has some gaps and limitations. The survey was conducted with a limited number of managers of exporting firms in various industries. The sample size could be enlarged and the research on the determinants of export performance will be established on a sector-specific basis, which will provide input to the different business areas.

\section{REFERENCES}

- Alexander, N., Rhodes, M., \& Myers, H. (2007). International market selection: measuring actions instead of intentions. Journal of services marketing, 21(6), pp. 424-434.

- Argenti, J. (1976). "Corporate Collapse: the causes and symptoms", Holsted Press, McGraw-Hill, London, 1st Edition.

- Arkolakis, C., Ramondo, N., Rodríguez-Clare, A., \& Yeaple, S. (2018). Innovation and production in the global economy. American Economic Review, 108(8), 2128-2173.

- $\quad$ Badriyah, N., Sari, R. N., \& Basri, Y. M. (2015). The effect of corporate governance and firm characteristics on firm performance and risk management as an intervening variable. Procedia Economics and Finance, 31, 868-875.

- Barringer, B. R., Jones, F. F., \& Neubaum, D. O. (2005). A quantitative content analysis of the characteristics of rapid-growth firms and their founders. Journal of business venturing, 20(5), 663-687.

- Beamish, P. W., Craig, R., \& McLellan, K. (1993). The performance characteristics of Canadian versus UK exporters in small and medium sized firms. MIR: Management International Review, 121-137.

- Ayed, O. B., \& Boujelbene, Y. (2013). Les déterminants de la performance des petites et moyennes entreprises exportatrices: cas de la Tunisie. Economics \& Strategic Management of Business Process, 2, 172-178.

- Bloemer, J., Pluymaekers, M., \& Odekerken, A. (2013). Trust and affective commitment as energizing forces for export performance. International Business Review, 22(2), 363-380.

- Calantone, R. J., Kim, D., Schmidt, J. B., \& Cavusgil, S. T. (2006). The influence of internal and external firm factors on international product adaptation strategy and export performance: a three-country comparison. Journal of Business Research, 59(2), 176-185.

- Clarke, J. E., Tamaschke, R., \& Liesch, P. W. (2013). International experience in international business research: A conceptualization and exploration of key themes. International Journal of Management Reviews, 15(3), 265-279.

- Damoah, O. B. O. (2018). A critical incident analysis of the export behaviour of SMEs: evidence from an emerging market. critical perspectives on international business, 14(2/3), 309-334.

- Downs Jr, G. W., \& Mohr, L. B. (1976). Conceptual issues in the study of innovation. Administrative science quarterly, 700-714.

- Dritsaki, C., \& Stiakakis, E. (2014). Foreign direct investments, exports, and economic growth in Croatia: A time series analysis. Procedia Economics and Finance, 14, 181-190.

- Durand, R., \& Coeurderoy, R. (2001). Age, order of entry, strategic orientation, and organizational performance. Journal of business venturing, 16(5), 471-494.

- $\quad$ Erdil, T. S., \& Özdemir, O. (2016). The determinants of relationship between marketing mix strategy and drivers of export performance in foreign markets: An application on Turkish clothing industry. Procedia-Social and Behavioral Sciences, 235, 546-556.

- Freeman, J., \& Styles, C. (2014). Does location matter to export performance?. International Marketing Review, 31(2), 181-208.

- Giarratana, M. S., \& Torrisi, S. (2010). Foreign entry and survival in a knowledge-intensive market: emerging economy countries' international linkages, technology competences, and firm experience. Strategic Entrepreneurship Journal, 4(1), 85-104.

- Haddoud, M. Y., Onjewu, A. K. E., Nowiński, W., \& Jones, P. (2021). The determinants of SMEs' export entry: A systematic review of the literature. Journal of Business Research, 125, 262-278.

- Hart, S. J., Webb, J. R., \& Jones, M. V. (1994). Export marketing research and the effect of export experience in industrial SMEs. International Marketing Review, 11(6), 4-22.

- Helm, R., \& Gritsch, S. (2014). Examining the influence of uncertainty on marketing mix strategy elements in emerging business to business export-markets. International Business Review, 23(2), 418-428.

- Jucà, M. N., \& Junior, E. H. (2021). "Tax benefit and bankruptcy cost of debt". The Quarterly Review of Economics and Finance, 81, 82-92.

- Johanson, J., \& Vahlne, J. E. (1977). The internationalization process of the firm - A model of knowledge development and increasing foreign market commitment. Journal of International Business Studies, 8, pp. $23-32$.

- Khelil, N., Smida, A., \& Zouaoui, M. (2012). Contribution à la compréhension de l'échec des nouvelles entreprises: exploration qualitative des multiples dimensions du phénomène. Revue de lEntrepreneuriat, 11(1), 39-72.

- Kogut, B., \& Singh, H. (1988). The effect of national culture on the choice of entry mode. Journal of international 
business studies, 19(3), 411-432.

- Kumlu, Ö. (2014). The effect of intangible resources and competitive strategies on the export performance of small and medium sized enterprises. Procedia-Social and Behavioral Sciences, 150, 24-34.

- Laghzaoui, S., \& Monnoyer-Longé, M. C. (2013). Engagement international et pratiques de veille stratégique: Cas des PME exportatrices. Marche et organisations, (2), 151-171.

- Lefebvre, E., Lefebvre, L. A., \& Bourgault, M. (1998). R\&D-related capabilities Small Business Economics, 10, pp. 365-377.

- Lelogeais, L. (2004). The role of qualitative variables in the early detection of default risk, Banque de France, Business Management, Business Monitor, 44-1356.

- $\quad$ Leonidou, L. C., Katsikeas, C. S., \& Samiee, S. (2002). Marketing strategy determinants of export performance: a meta-analysis. Journal of Business research, 55(1), 51-67.

- Lumpkin, G. T., \& Dess, G. G. (1996). Clarifying the entrepreneurial orientation construct and linking it to performance. Academy of management Review, 21(1), 135-172.

- Mansion, S. E., \& Bausch, A. (2020). Intangible assets and SMEs' export behavior: a meta-analytical perspective. Small Business Economics, 55(3), 727-760.

- Maurel, C. (2009). Determinants of export performance in SMEs: the case of the French wine industry, International Journal of Wine Business Research, 21(2), 118-142.

- Miečinskienè, A., Stasytytè, V., \& Kazlauskaitė, J. (2014). Reasoning of export market selection. Procedia-Social and Behavioral Sciences, 110, 1166-1175.

- $\quad$ Namiki, N. (1988). Export strategy for small business. Journal of Small Business Management, 26(2), 32-37.

- Ogunmokun, G., \& Ng, S. (2004). Factors influencing export performance in international marketing: A study of Australian firms. International Journal of Management, 21(2), 172-185.

- Porter. (1985). The Competitive Advantage: Creating and Sustaining Superior Performance Free Press, NY.

- Ropega, J. (2011). The reasons and symptoms of failure in SME. International Advances in Economic Research, 17(4), 476-483.

- $\quad$ Singh, D. A. (2009). Export performance of emerging market firms. International Business Review, 18(4), 321-330.

- Wagner, J. (2001). A note of the firm size-export relationship, Small Business Economics, 17(4), pp 229-237.

Wasilczuk, J. (2000). Advantageous competence of owner/managers to grow the firm in Poland: Empirical evidence. Journal of small business management, 38(2), 88-94.

\section{Appendix}

\begin{tabular}{|c|c|c|c|c|c|c|c|c|c|c|c|c|c|c|c|c|c|c|c|c|c|}
\hline & 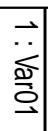 & 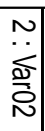 & $\begin{array}{l}\omega \\
\stackrel{\omega}{0} \\
\stackrel{0}{5} \\
\omega\end{array}$ & 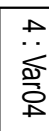 & $\begin{array}{l}\text { ज } \\
\stackrel{9}{5} \\
\text { ci }\end{array}$ & 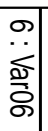 & 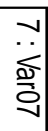 & $\begin{array}{l}\infty \\
\ddot{0} \\
\stackrel{0}{\circ} \\
\infty\end{array}$ & 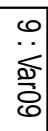 & $\begin{array}{l}\overrightarrow{0} \\
\stackrel{0}{\cong} \\
\stackrel{\partial}{\partial}\end{array}$ & 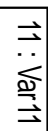 & $\begin{array}{l}\vec{N} \\
\stackrel{0}{\cong} \\
\stackrel{N}{N}\end{array}$ & 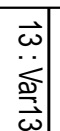 & 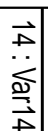 & $\begin{array}{l}\vec{v} \\
\ddot{\Phi} \\
\stackrel{\Xi}{v}\end{array}$ & 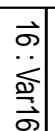 & $\begin{array}{l}\vec{v} \\
\ddot{\aleph} \\
\stackrel{\Xi}{\vec{v}}\end{array}$ & 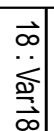 & 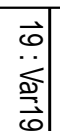 & 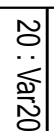 & 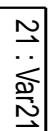 \\
\hline : Var01 & 0 & 3 & 1 & 1 & 0 & 1 & 2 & 1 & 1 & 3 & 1 & 1 & 2 & 1 & 2 & 0 & 0 & 0 & 1 & 0 & 1 \\
\hline : Var02 & 2 & 0 & 3 & 2 & 1 & 2 & 1 & 1 & 1 & 0 & 1 & 0 & 0 & 0 & 1 & 1 & 0 & 1 & 0 & 0 & 1 \\
\hline 3: Var03 & 3 & 2 & 0 & 2 & 0 & 0 & 0 & 0 & 2 & 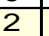 & 1 & 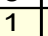 & 5 & 0 & 0 & 2 & 2 & 1 & 0 & 0 & 2 \\
\hline 4: VarO4 & 2 & 1 & 1 & 0 & 1 & 0 & 1 & 0 & 0 & 1 & 0 & 1 & 0 & 2 & 0 & 1 & 1 & 2 & 0 & 1 & 0 \\
\hline 5: Var05 & 0 & 1 & 0 & 2 & 0 & 0 & 1 & 0 & 0 & 0 & 5 & 1 & 0 & 1 & 0 & 1 & 1 & 1 & 0 & 0 & 1 \\
\hline 6: Var06 & 0 & 2 & 1 & \begin{tabular}{|l|}
0 \\
\end{tabular} & 3 & 0 & 0 & 0 & 2 & 0 & 0 & 0 & 1 & 1 & 1 & 1 & 0 & 3 & 1 & 0 & 0 \\
\hline 7: Var07 & 1 & 1 & 2 & 1 & 0 & 1 & 0 & 0 & 2 & 1 & 2 & 0 & 0 & 0 & 0 & 0 & 1 & 3 & 1 & 0 & 1 \\
\hline 8: Var08 & 3 & 2 & 0 & 1 & 0 & 1 & 2 & 0 & 1 & 0 & 3 & 0 & 0 & 0 & 0 & 1 & 1 & 0 & 1 & 1 & 0 \\
\hline 9: Var09 & 2 & 0 & 0 & 0 & 1 & 0 & 0 & 2 & 0 & 0 & 0 & 1 & 1 & 0 & 0 & 0 & 1 & 0 & 0 & 1 & 1 \\
\hline $10: \operatorname{Var} 10$ & 1 & 0 & 1 & 0 & 2 & 0 & 1 & 1 & 0 & 0 & 0 & 1 & 1 & 1 & 1 & 0 & 2 & 0 & 2 & 0 & 2 \\
\hline $11: \operatorname{Var} 11$ & 1 & 1 & 0 & 0 & 2 & $\frac{2}{2}$ & 1 & 1 & 2 & 0 & 0 & 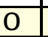 & 1 & 1 & 0 & 0 & 1 & 0 & 1 & 0 & 0 \\
\hline $12: \operatorname{Var} 12$ & 0 & 0 & 1 & 0 & 1 & $\overline{0}$ & 0 & 0 & 2 & 1 & 0 & 0 & 0 & 0 & 0 & 1 & 0 & 1 & 1 & 0 & 0 \\
\hline $13: \operatorname{Var} 13$ & 1 & 0 & 1 & 1 & 0 & 1 & 0 & 0 & 0 & 1 & 2 & 0 & 0 & 0 & 0 & 0 & 0 & 0 & 0 & 0 & 1 \\
\hline $14: \operatorname{Var} 14$ & 1 & 2 & 0 & 1 & 1 & 1 & 2 & 0 & 0 & 2 & 2 & 2 & 0 & 0 & 0 & 1 & 2 & 2 & 0 & 2 & 1 \\
\hline $15: \operatorname{Var} 15$ & 1 & 1 & 0 & 1 & 0 & 1 & 1 & 2 & 1 & 0 & 0 & 3 & 2 & 1 & 0 & 0 & 1 & 1 & 3 & 2 & 0 \\
\hline $16:$ Var16 & 0 & 0 & 1 & 2 & 0 & 0 & 0 & 3 & 1 & 1 & 1 & 2 & 1 & 1 & 3 & 0 & 1 & 1 & 0 & 1 & 3 \\
\hline $17: \operatorname{Var} 17$ & 0 & 1 & 0 & 0 & 1 & 3 & 0 & 0 & 0 & 4 & 1 & 1 & 1 & 0 & 1 & 2 & 0 & 0 & 2 & 0 & 0 \\
\hline $18: \operatorname{Var} 18$ & 0 & 0 & 3 & 0 & 0 & $\frac{2}{2}$ & 1 & 0 & 2 & 0 & 1 & 0 & 0 & 2 & 2 & 2 & 0 & 0 & 1 & 0 & 2 \\
\hline $19:$ Var19 & 0 & 0 & 0 & 1 & 1 & $\frac{1}{1}$ & 0 & 1 & 2 & 0 & 3 & 1 & 1 & 1 & 0 & 0 & 0 & 0 & 0 & 3 & $\frac{1}{1}$ \\
\hline $20:$ Var20 & 0 & 1 & 0 & \begin{tabular}{|l}
1 \\
\end{tabular} & 0 & 0 & 1 & 0 & 1 & I & 2 & I & 1 & 1 & 1 & 0 & 1 & 1 & 2 & 0 & 3 \\
\hline $21:$ Var21 & 1 & 1 & 0 & 0 & 1 & 1 & 0 & 1 & 1 & 1 & 1 & 1 & 1 & 1 & 1 & 2 & 2 & 1 & 3 & 1 & 0 \\
\hline
\end{tabular}

Figure 4: The structural analysis matrix

CITATION: Mohamed Sofien Nouri \& Younes Boujelbene (2022). Determinants of the Export Performance of Tunisian SMEs: Analysis Trough the MICMAC Method. South Asian Res J Bus Manag, 4(1), 1-10. 